An adult male specimen from Pinawa, 9 December 1979, had three white belly feathers and one white inner flank feather. An adult female captured at Lac du Bonnet, 8 December 1979, had a white section on one web at the tip of the third primary on the right wing. An adult female captured on 3 February 1980 near Elma had one main inner left scapular feather that was all white. This feature was first noticed in the field by John Christie who thought the bird had been marked after banding. An adult female captured on 1 June 1981 at Wabowden had two white feathers in the facial disk above the left eye and a few white feathers in the tertial area of one wing.

I was fortunate to be assisting Herb Copland and Bob Nero in banding owls at a nest near Marchand on 6 and 9 June 1984. The adult female at this nest had a tuft of more than 14 white feathers on the upper left side of the breast; these were concealed by the long breast feathers but were noticed while the bird was being inspected. Of greater interest was my discovery of an unpigmented and horn-coloured talon on the same toe of each of the three young from this nest. Neither the female nor the male parent showed any abnormal depigmentation of their talons. The occurrence of a common, specific albinistic feature, namely lack of pigment in the talon of the outer front toe on the right foot of each of three young in one nest, suggests a genetic aberration.

Kay McKeever, Owl Rehabilitation Research Foundation, Vineland, Ontario, has an adult male Great Gray Owl with one white undertail covert, and an adult female with a white scapular feather. In both cases, these single white feathers have been replaced annually for the past six years, indicating permanent follicle damage interfering with deposition of pigment (pers. comm., 1984).
I would like to thank Robert W. Nero for assisting me with the preparation of this note.

\section{MANITOBA GREAT GRAY OWL RESEARCH PROJECT ANNOUNCED}

MERLIN W. SHOESMITH, Chief, Biological Services, Manitoba Wildlife Branch, Box 14, 1495 St. James Street, Winnipeg, Manitoba R3H OW9.

The most ambitious non-game research project yet undertaken under the auspices of the Manitoba Wildilife Branch was initiated in April 1984. This is a 4-year radio-telemetry study of the Great Gray Owl, designed to provide information on the movements of a known breeding population over a 4-year period. Use of habitat in all seasons and from year to year is expected to shed considerable light on the habitat requirements of this large raptor.

This project resulted from discussions between Bob Nero and Steven L. Loch, Foley Minnesota. As is generally known, Bob Nero and his colleagues (especially Herb Copland, Manitoba Museum of Man and Nature) have been studying the Great Gray Owl for more than 15 years. For the past 4.5 years, Loch has been using radio-telemetry to study Great Gray Owls in Minnesota under Professor Al Grewe, St. Cloud State IJniversity. In November 1983, Loch resigned from a full-time position with Minnesota Department of Natural Resources to take on the major role in the Manitoba project.

By 11 July 1984 there were radiotransmitters on 25 Great Gray Owls, including males, females and young, 
in an area about 50 miles southeast of Winnipeg. Loch plans to radio-mark an additional 5 young from this breeding population in the near future. The complement of 30 radio-marked owls will provide the basis for the 4-year study.

Maria Servos, a graduate student at the Natural Resources Institute, University of Manitoba, is already engaged in tracking the movements of four of these radio-marked owl families in relationship to their use of habitat. She is being assisted by Cheryl-Dawn Russell, a STEP student assigned to work on Great Gray Owls under the supervision of Bob Nero.

Sponsors of this unusual research project are:

- Manitoba Department of Natural Resources

- World Wildlife Fund Canada

- Murphy Foundation Ltd.

- Manitoba Naturalists Society
- Manitoba Wildlife Federation

- Lac du Bonnet Wildlife Association

- Selkirk Centennial School

Telemetry equipment has been supplied on loan from the U.S. Fish and Wildlife Service, the Canadian Wildlife Service and Ontario Ministry of Natural Resources. Except for Manitoba DNR funds, grants are being administered through the services of the Natural Resources Institute, University of Manitoba.

We are grateful to the officials of the above organizations for granting funds and loaning equipment in support of this project. Anyone wishing to contribute funds is welcome to do so. Funds should be sent to the "Great Gray Owl project" in care of Dr. Walter Henson, Director, Natural Resources Institute, University of Manitoba, 177 Dysart Road, Winnipeg, Manitoba R3T 2 N6.

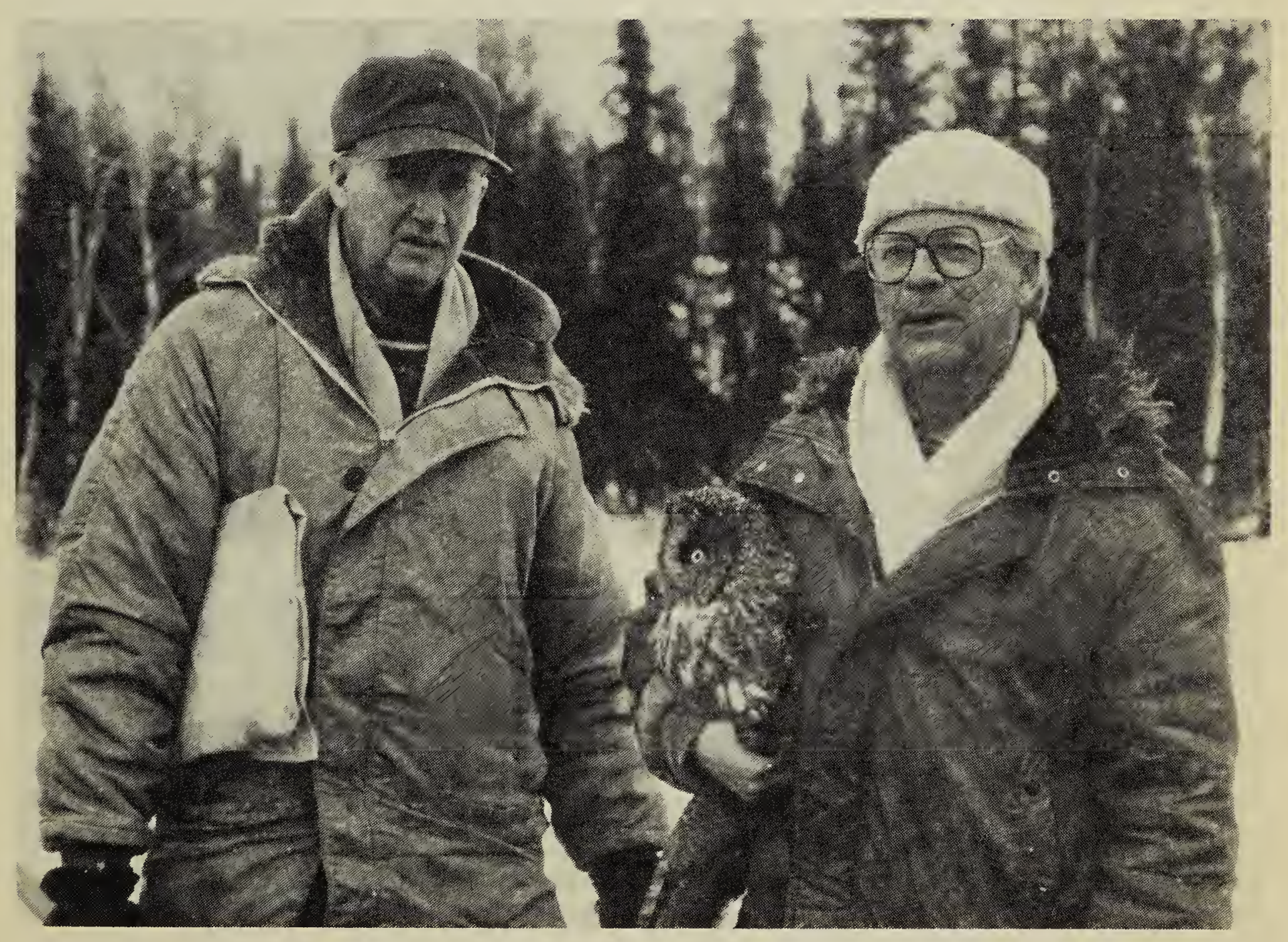

